\title{
The Violation on Women's Rights in the Unilateral Divorce in Sasak Community From A Feminist Legal Theory
}

\author{
Zulfatun Ni'mah \\ (Fakultas Syariah dan Ilmu Hukum IAIN Tulungagung, Jl. Mayor Sujadi Timur \\ No.46 Tulungagung, Email:zulfa_ma@yahoo.com)
}

\begin{abstract}
Abstrak:
Undang-Undang Perkawinan Indonesia mengatur bahwa perceraian harus dilaksanakan di pengadilan. Namun, masyarakat Sasak di Lombok masih banyak yang mempraktikkan perceraian di luar pengadilan, yakni dengan pernyataan sepihak suami kepada istri. Ditinjau dari perspektif teori hukum feminis, perceraian sepihak rentan mengakibatkan terlanggarnya hak-hak perempuan, karena hukum yang sesungguhnya hidup di masyarakat pada umumnya dirumuskan oleh laki-laki, menggunakan perspektif laki-laki dan bertujuan untuk melanggengkan kekuasaan laki-laki. Penelitian ini bertujuan untuk mendeskripsikan bentuk-bentuk pelanggaran hak perempuan Sasak yang diceraikan secara sepihak oleh suaminya dan menganalisis dengan perspektif teori hukum feminis. Penelitian ini merupakan jenis penelitian hukum empiris yang menggunakan pendekatan kualitatif. Data primer diambil dari responden, narasumber melalui teknik wawancara mendalam dan observasi non partisipatoris. Hasil penelitian menunjukkan bahwa terdapat empat bentuk pelanggaran hak perempuan yang diceraikan secara sepihak, yaitu: a) tidak mendapatkan mut'ah dan nafkah masa iddah; b) tidak mendapat pelunasan maskawin; c) tidak mendapat bagian atas harta bersama; dan d) tidak mendapat kepastian akan status jandanya. Berdasarkan temuan ini, penting untuk dilakukan program literasi hukum bagi masyarakat Sasak agar tidak bercerai secara sepihak lagi.
\end{abstract}

\section{Kata Kunci :}

Pelanggaran Hak, Perempuan, Perceraian sepihak

\begin{abstract}
For giving legal protection to both of husband and wife, Indonesian Marriage Act 1/1974 regulate that a divorce should be done in the court. However, until recently there are many Sasak men still divorced their wives by unilateral statement only, not through trial process in the court. From a feminist legal theory perspective, the practice of unilateral divorce was susceptible to violate women's right
\end{abstract}

al-Ihkâm Vol.13 No.1 Juni 2018

DOI 10.19105/al-ihkam.v13i1.1482 


\section{Zulfatun Ni'mah}

because empirically the living law in the community is generally formulated by male figures, using man perspective and aim for perpetuate men power. This research aims to describe and analyse the forms of violation of the rights of Sasak women who was unilaterally divorced by her husband. This research is a type of empirical legal research using qualitative approach. Primary data is taken from the subject of research, by in-depth interview technique and nonparticipatory observation. The result of research shows that there are four types of violation on women's rights who are divorced by their husband, namely: a) not getting mut'ah (competation of divorce) and basic necessity during 'iddah; b) not getting the settlement for mahr; c) not getting the share of community property; and d) not having certain marital status. Base on this result, it is very important to conduct a legal literacy program for Sasak community for make them not divorce unilaterally anymore.

\section{Keywords :}

Rights Violation, Women, Unilateral Divorce

\section{Introduction}

Indonesian marriage law idealizes marriage as a noble, innerdimensional bond between men and women to create a happy and eternal family forever. This idealists is listed in Article 1 paragraph (1) of Act Number 1 of 1974 on Marriage. In connection with this ideal, marriage law embraces six principles, among which is the principle of complicated divorce. ${ }^{1}$ According to Article 39 of this Act, the principle of complicated divorce is, among others, applied in the form of enactment of a provision stating that a divorce can only be made before a court hearing after the related court has made an effort and unsuccessfully reconcile both parties ${ }^{2}$. This means that both husband

1Amiur Nuruddin, Azhari Akmal Tarigan, Hukum Perdata Islam di Indonesia: Studi Kritis Perkembangan Hukum Islam dari Fikih, UU no. 1/1974, sampai KHI, (Jakarta: Kencana, 2004), 47

2Article 65 of Law No. 7 of 1989 jo Law No. 3 of 2006 Jo Article 39 of Law No. 1 Year 1974. The Civil Procedure Law in the Religious Courts provides that on every occasion, particularly at the beginning of the trial, the panel of judges examining divorce issues is required to try to reconcile the parties. See: Yahya Harahap, Kedudukan, Kewenangan dan Acara Peradilan Agama, (Jakarta: Garuda Metropolitan Press, 1993) 50-51 
and wife, whether unilaterally or by mutual consent, are not justified in divorce without the involvement of a judge in the court. The involvement of the court as an institution authorized to make the decision of divorce cases according to Mukti Arto is intended to ensure justice for both parties so that their rights are fulfilled. ${ }^{3}$ Practically, in many places, involvement of the court in the divorce process demonstrate better protection for women's right. For example, Susylawati's research show that in Pamekasan Religious Court, a woman who divorced by her husband got maintenance charge for iddah period after she propose it to judges. Another woman, get maintenance charge for iddah and also settlement for maintenance charge that he did'nt pay before divorce during four months. ${ }^{4}$

Different from the above normative provision, to this day the Sasak community in Lombok Island still practicing the divorce through one-sided statement made by the husband, without the involvement of the court. ${ }^{5}$ This divorce practice based its validity on the understanding of divorce contained in Islamic law which state that divorce is the husband's right to be used with an oral or gesture statement, and can be legal even if it is pronounced jokingly, in a state of anger, or even when drunk. ${ }^{6}$ Theoretically, based on the feminist legal theory, the practice of law which is left entirely to the vulnerable men results in marginalization of women. This is because the real

\footnotetext{
3 Mukti Arto, Mencari Keadilan, Kritik dan Solusi terhadap Praktik Peradilan Perdata di Indonesia, (Yogyakarta: Pustaka Pelajar, 2001), 122

${ }^{4}$ Eka Susylawati, Moh. Masyhur Abadi, H. M. Latief Mahmud, "Pelaksanaan Putusan Nafkah Istri Pasca Cerai Talak di Pengadilan agama Pamekasan, Jurnal Al Ihkam, STAI Pamekasan, Vol. 8. No. 2 Tahun 2013, http://ejournal.stainpamekasan.ac.id/index.php/alihkam/article/view/354/345, diakses tanggal 1 Mei 2018.

${ }^{5}$ Hamzan Wahyudi, "Tradisi Kawin Cerai Masyarakat Adat Suku Sasak serta Akibat Hukum yang Ditimbulkan, (Thesis at Postgraduate Program, Diponegoro University, Semarang, 2004), 86. Nur Yasin, Praktik Kawin Cerai Bawah Tangan di Kalangan Masyarakat Muslim Sasak di Kota Mataram, (Malang: UIN Malang Press, 2008), 1. Wini Tamtiari, Awig-awig Awig-awig Melindungi Perempuan dari Kekerasan?, (Yogyakarta: PSKK UGM dan Ford Foundation, 2005), 37.

6 Zulfatun Ni'mah dan Nur Fadhilah, "Pluralisme Hukum Perceraian pada Masyarakat Sasak di Pulau Lombok dan Implikasinya terhadap Pelaksanaan Hak-hak Perempuan Pascaperceraian", Laporan Penelitian, Unpublished, 2016, : 100
} 
laws of life in society are generally formulated by the male figures, using a male perspective and aiming to perpetuate the power of men.

Based on the theoritical assumption above, this research guessed that unilateral divorce practice on Sasak community are susceptible cause of the violations right of the divorced women. This allegations appear based on feminist legal theory, that practice law submitted fully to man are susceptible cause of marginalization to women. It is because, realisticly the living law in the community is generally formulated by male figures, using man perspective and aim for perpetuate men power. ${ }^{7}$

Emily Snider mentions that practice law implemented by custom community need to be seen critically because it is often modified by the local custom values that load discrimination to women. ${ }^{8}$ The rights referred to Article 149 of the Compilation of Islamic Law which states that if the marriage is terminated due to divorce, then the husband has four obligations to his ex-wife, namely: giving a decent mut'ah, whether in the form of money or objects, unless there is no sexual relationship between them; ; paying for basic necessity, maskan ${ }^{10}$, and kiswah ${ }^{11}$ as long as the wife undergoes the iddah period, unless the former wife has been sentenced to divorce bain or nusyuz and in a state of pregnancy, paying the dowry which is still payable entirely, if between them has occurred sexual relationship, but if it has not happened yet, then the husband is only obligated to pay half of mahr that has been promised.

\section{Research Methods}

This research is a type of empirical law research using qualitative approach. This research was conducted in three villages in central Lombok and on village in east Lombok regency. The

\footnotetext{
7 Agnes Widanti, Hukum Berkeadilan Jender, Aksi Interaksi Kelompok Buruh Perempuan dalam Perubahan Sosial, (Jakarta: Kompas, 2005), 27

${ }^{8}$ Emily Snider, "Indigenous Feminist Legal Theory", https://www.utpjournals.press/doi/full/10.3138/cjwl.26.2.07, accessed on Februari 27, 2018.

${ }^{9} \mathrm{Mut}$ 'ah is a grant from former husband to a former wife who was handed a divorce in the form of object or money and others. Ahmad Syaifuddin, Hukum Perceraian, (Jakarta: Sinar Grafika, 2013),. 406.

10 Maskan is another word of residence.

11 Kiswah another word of clothing.
} 
considerations in choosing these villages are partly because the ease to find the people with unilateral divorce experience and willing to share their experience. The research subject is divided into two, namely respondent and information sources. The respondent is research subject from people who have experienced the unilateral divorce by themselves, consisting of male and female. In addition to personal experience, primary data was also collected from research subject categorized as information sources..$^{12}$ The sources of this research are local leaders, consisting ustadz and kyai, and scientist from an university.

Data in this research was gathered through in-depth interview technique, observation, document study. ${ }^{13}$ Interview is used to collect data from respondents and information sources. Observation is used to learn the social relation between individuals in the society and socio-cultural values that surround the community, both in the family environment and wider community. The document study used to collect secondary data from literature review materials, either in the form of positive law, doctrine, research result and textbook. Data analysis in this research refered to the interactive model introduced by Miles and Huberman, which consists of three inter-related processes, namely data reduction, data display and conclusion. ${ }^{14}$

\section{Discussion}

\section{Unilateral Divorce Practice}

Generally, it can be said that the Sasak community in all research locations, either in village Komak, Antap, Balap or Kelor there was unilaterall divorce practice. In this case, the unilateral

\footnotetext{
12 Referring to Hardiansyah, the information sources is a person who knows the issues studied but does not experience directly. Herdiansyah, Haris. Wawancara, Observasi dan Focus Group sebagai Instrumen Penggalian Data Kualitatif, (Jakarta: Rajawali Pers, 2013), 67.

13Ibid., 63. Participatory oversight is the activity of the researcher to observe the object and the subject of research by directly involving themselves in activities related to the research theme. Setya Yuwana Labankan, "Ragam Metode Pengumpulan Data ; Mengulas Kembali Pengamatan, Wawancara, Analisis Life History, Analisis Folklore", in Burhan Bungin (Ed), Metodologi Penelitian Kualitatif, Aktualisasi Metodologis ke Arah Ragam Varian Kontemporer, (Jakarta: Rajawali Pers, 2011), 89

14 Mathew Miles dan Michael Huberman, Analisis Data Kualitatif, (Jakarta: UI Press, 1990), 15.
} 
divorce refers to the act of deciding marriage by using divorce instrument made on the will and decision of one party only, which is the husband party and it is stated on one-sided statement of the husband, without involving the institution that has the authority to control the divorce. In details, there are at least two criteria referred to in defining one-sided divorce in this study: First, the decision to declare divorce was taken solely by the husband, on the basis of the husband's subjective interests only. That is, decision-making is not always based on legitimate reasons in accordance with the provisions of legislation. ${ }^{15}$ Second, the divorce statement was disclosed by the husband without the consent of the judge and without going through the judicial process. In the following sections will be disclosed unilateral divorce practices found in the study sites.

\section{Patterns of Unilateral Divorce Statement}

Based on the way of expressing it, there are four unilateral divorce patterns practiced by the Sasak community. First, the husband declares the divorce directly to his wife face-to-face. In this pattern, the unilateral divorce is done through divorce or divorce statement made by the husband directly to the wife, in the presence of his wife and heard directly by him. This statement is sometimes spoken systematically, with sentences that show the deliberate imposition of divorce, sometimes just a reaction to a particular situation that triggers the husband to divorce her. The debate about several matters between husband and wife is not uncommon to lead to the utterance of the word divorce which by society is understood as an act that resulted in the end of marriage.

Direct divorce statement is sometimes pronounced straightforwardly by using a word which means divorce can be easily understood by the wife, sometimes it is disguised in another sentence that is incomprehensible at once. The straightforward statements include, "I divorce you," "I want to divorce you", while statements in disguised sentences such as "Go back to your parents", "Pack your bags, I will take you to your parents' home". Both straightforward and disguised statements, divorce statements are usually clarified

\footnotetext{
15 There are 6 circumstances validated by legislation as legitimate reasons for divorce
} regulated by Government Regulation No. 9 of 1975. 
beforehand because the divorce statement is often pronounced unexpectedly without being preceded by a conversation that leads to the intention of divorce. One respondent reported that she had to listen her husband's divorce statement with straightforward statements, but she responded to her husband statement with ease she did not think that her husband really meant it. 16

Both straightforward and disguised divorce statements, by local communities and authorities recognized as valid divorce. Based on several information sources, the basis of the validity of both is the Islamic law mazhab Syafii. ${ }^{17}$ Based on the literature study in this research, it is found that some classic fiqh literature containing such doctrine, among others in Fath al-Mu'in. In this book, Al Fanani explains that divorce can be stated through straightforward statements and disguised statements. Straightforward statement is considered to be valid if the object is clear, for example, "I divorce you". "My wife name Fatime, I divorce you". Meanwhile, the disguised statements can be recognized its validity if accompanied by the intention of divorcing. ${ }^{18}$ The disguised statements exemplified by Al Fanani include, "You are now forbidden to me", and "The woman who used to be lawful for me but now you are forbidden for me". ${ }^{19}$

Second, the husband states that the divorce in front of others, then the person who hears it tell the wife. In this pattern, the element needed as the requirements of valid divorce are the husband and divorce statement and on of the witnesses who hears the statement. According to the respondents, criteria for people who can be accepted the witnessing is one adult male. ${ }^{20}$ In this case, the existence of the wife as a divorced party can also be ignored so it is very common for a wife who knows that she is divorced by her husband from other people. ${ }^{21}$ That is, the divorce can be done in a very informal situation.

\footnotetext{
16Interview with Gesipa as respondent on September 21, 014

17Interview with Haji Awaludin as the information sources from religious leaders on January 20, 2015. Interview with Kyai Diralim as the information sources on September 19, 2015.

18 Zainuddin bin Abdul Azizi Al Malibari Al Fanani, Fathul Mu'in, Translated by Moch. Anwar, (Bandung: Sinar Baru Algesindo, 2014), 1360-1361

19Ibid., 1366

${ }^{20}$ Interview with Musinah, Adila and Saniyah as respondents on October 1, 2016

${ }^{21}$ Interview with Rohawi as respondent dated January 25, 2015
} 
It is called that way because women can be divorced through the notices of others, so the wife as a divorced party does not hear the statement by herself. There is an impression that the divorce is considered to be the same as ordinary conversation that does not result in serious legal consequences. That is, divorce is seen as trivial so that it can be delivered through others. This trivial impression is clearly seem because it can startled the wife where she can be divorced without being preceded by the discussion leading to the divorce itself.

Third, the husband states the divorce through the phone. The third unilateral divorce pattern is stated by the husband from a distance through phone. In this pattern, there are two ways of declaring the divorce, which is directly to the wife or other people. In Komak and Antap village, if the husband states directly to the wife, usually the wife will report it to the head of the hamlet and the head of the hamlet along with the religious leaders will clarify the words of the husband's divorce by phone witnessed by the husband's family member.If the husband justifies the statement, then the urban village head and religious leader are considered as witnesses of the divorce. Similarly, if the husband declares to others that he has divorced his wife, then on the report of his wife or the person who heard it then the urban village head and religious leader ask clarification to the husband. A family clarification request is important to ensure that the person who makes the call is the actual husband of the wife and really intends to declare the divorce. ${ }^{22}$

The different circumstances are found in Balap and Kelor villages, where the divorce is done through phone is not directly reported to the urban village head or religious leader but is accepted as ordinary news. These two villages can be said as the regions with the most inhabitants working overseas, thus there are many married couples living separately in two different countries. There are many

\footnotetext{
${ }^{22}$ One of the women from Komak village who had been divorced by phone told me that after working for one year in Malaysia, suddenly her husband called and declared divorce. He was extemely surprised, because previously there was no fight that led to the divorce. Her husband rarely calls, but she thinks they have no serious problems that will lead to a divorce. However, after the phone conversation ended, he immediately packed up to leave her husband's house. Interview with Sarjet as respondent on September 15, 2014
} 
cases in which the husband lives in the village and decides to divorce the wife who works overseas through phone. Conversely, there are many husbands working abroad and decides to divorce his wife in the village through phone. ${ }^{23}$

Fourth, the husband states the divorce in front of the local authority. For Lombok community in general, the urban village head is the public figure as well as the nearest government officers that can be accessed. In the case of family dispute leads to a divorce, the residents of a village involved in the dispute may contact the head of the village in his residence. Because divorce is considered closely related to religion, in general the urban village head needs to involve the religious leader as the representative of the religious figure. These figures then held a family discussion, which is by bringing together two parties and their family members to reconcile. ${ }^{24}$ However, if it cannot be reconciled, the urban village head and religious leader ask the husband's part to declare the divorce with a clear sentence so that it can be understood by all parties present.

Another variant is when the husband declares the divorce outside the knowledge of the urban village head and the wife later reports it to the urban village head. In this last case, the urban village usually asks the clarification of the report from the wife who is divorced by her husband and asks the husband to declare it clearly one more time to be witnessed by the urban village head and the religious leader.After it is clear that the intention is to divorce, the husband side will ask how many 'talak' will be given to the wife, for example, one, two or three directly at once. This clarification is especially applicable to husband who previously declares divorce with a lack of clarity. A village marriage celebrant says that his party is necessary to lead the husband to declare the divorce but by clarifying in advance about what he meant. ${ }^{25}$

The fourth pattern mentioned above indicate that the divorce recognized by the Sasak community should fulfil at least two

${ }^{23}$ Interview with Kyai Abdurahim as the information source from religious leaders on October 6, 2016

${ }^{24}$ Interview with Samsul as the information sources as the urban village head of Renong on September 24, 014

${ }^{25}$ Interview with Kyai Minun as the information sources from religious leaders of Kelor village on February 2, 2015. 
elements, which is the divorce statement made by the husband and one or more witnesses. The parties in which the witnessing is accepted at least one male, either from the community or someone with territorial and religious authority. The testimony may be received from the person who claims to hear the divorce statement, either hear it unintentionally or intentionally. Hearing intentionally means that the related party is asked to witness it by the husband who will declare the divorce, meanwhile hearing unintentionally means that the husband states the divorce without any planning and the person is accidently hear it. Hearing unintentionally often happens in the divorce case because the husband cannot control his own emotion for example when he is angry or jealous over his wife.

\section{Violations of Women's Rights on Unilateral Divorce}

\section{a. Does Not Receive Mut'ah and Basic Necessity During Iddah}

All of the wives who have heard the divorce statements have an understanding that their marriage is immediately over. Based on this understanding, all respondents who were unilaterally divorced took the attitude of leaving her husband's house to return to their parents' house. Some of them were taken to the parents' house with their husband, others were picked up by their family members, others had to go back home alone.

Of all respondents interviewed, none provided information about the fulfillment of the former wife's rights in the form of mut'ah and the living of this iddah period. The neglect of this right is caused by the lack of public knowledge about mut'ah. Both male and female respondents do not know about the obligation of ex-husbands to give mut'ah, both from Islamic law and Indonesian law. The breakup of marriage resulted in the breaking of all rights and obligations. The lack of knowledge of the right of mut'ah and the basic necessity of this iddah period is the result of imbalance law socialization.

The socialization of the law on divorce has so far been partial, in which the right of men to declare divorce is socialized to the society, while the obligation of men after declaring the divorce is not socialized:

"It is true that within three months after being divorced, a wife is not allowed to remarry, it is called iddah period. However, we never talked about the livelihood for the wife while she is in iddah period, because 
according to the custom around here, a woman should return home after being divorced. The livelihood will be provided by her father or her family since the husband is no longer responsible to provide, that is the point of divorce"," 26

" "We always reminded the divorced wives that they must go through iddah period, but we never suggested the husbands about providing livelihood during iddah period. It would be weird, since a divorce is a shame to the woman, she will return to her family's house, so there is no really a point in talking about livelihood." 27

Another cause is the existence of social values that are usually gender biased, which is the existence of shame construction that pressures women. According to information sources, it is taboo and embarrassing to ask for something from former husband because they consider that marriage has been broken by sharia. In addition, women have also been invested in social values to feel ashamed if they do not leave their husbands' home immediately after being divorced. Indirectly, these shame construction cause women to be hampered to claim their rights because violations of these social values are at risk of exposing them to social sanctions, such as gossip, mockery and isolation. ${ }^{28}$

\section{b. Does Not Receive the Repayment of Dowry}

Based on the provision of Islamic law, women are entitled to the dowry of the man who married her. This provision is stipulated in Q.S al-Nisa' 4: 4 which can be translated into: "And give to the women (that you marry) dowry". The obligation to pay the dowry is supported by KHI that is in Articles 30 to $38 .{ }^{29}$ Dowry can be given in cash at the time of marriage and the payment can also be postponed and become the husband's debt to the wife. Based on Article 149 Compilation of Islamic law, the husband who divorces his wife shall

26 Interview with Kyai Dailun as the information source from religious leader of Kelor village on September 23, 2014

${ }^{27}$ Interview with Kyai Minun as the information sources from religious leaders of Kelor village on February 2, 2015.

28 Interview dengan Baiq Mulianah as a from Universitas Nahdlatul Ulama NTB on September, 232014

${ }^{29}$ Article $30 \mathrm{KHI}$ : The prospective groom shall pay the dowry to the prospective bride whose amount, form and type agreed upon by both parties. 
pay the owed dowry. The provision is also found in the literature of classical Islamic law.

It's different from these provisions, this study found that some female respondents who lost access to the dowry redemption because the husband refused to pay the promised dowry at the time of the marriage ceremony. The first respondent, a scholar, was promised a dowry of 10 grams of gold in the marriage ceremony. At the time of the marriage ceremony took place, she received only 5 grams of gold, a ring, while the rest that has been promised will be given later. The promise was not fulfilled by her husband until a year later when he divorced her, he has not paid it off. The respondent have tried to invoice verbally on various occasions, but her former husband is always evasive. At the time of this research took place, the divorce has passed by 6 years and the dowry has not been paid. These respondents actually carry out their divorce through state judicial mechanisms, but their access to justice through courts is restricted by information in a marriage book stating that dowries have been paid in $\operatorname{cash}^{30}$.

"I was promised 10-gram of gold, and I was given 5-gram of it at akad. However, a few days later his mother proposed to borrow the gold and said that it will be returned along with another 5-gram. One year later we divorced when our child is only 2-months old. I was divorced in my parents' house, before my parents, before my family. When I was divorced, he did not pay off the rest of the dowry promised only to acknowledged that it has not been paid off. I have asked about it relentlessly, and it has been 6 years since our divorce and I still see no signs that he is going to pay it off. That is why I have to let it go." 31

Another respondent, two women who married the same men in not so different span of time. They are both promised to get the same dowry, which is a ticket to hajj fare in 2016. Under the provision of Hajj Fee $(\mathrm{ONH})$ from the Ministry of Religious Affairs, ONH ticket is worth the value of $37,800,000$. However, not until the promised Hajj season.

"He made a prenuptial agreement to give me a dowry in the form of hajj tickets. But he divorced me after a month of marriage. When I asked for the dowry repayment he refused. Instead of paying off, he even leases 5

\footnotetext{
30 Interview with Adilah as the respondent on September 30, 2016

31 Interview with Adilah as the respondent on September 30, 2016
} 
lawyers to block the repayment. After I was divorced, I demanded that he pay the price but he did not want to. Instead, he put me in dark, I bitterly concede, and ask him to divorce me even though the dowry is not paid. How else is it going to be? I would rather lose my money than bear with uncertain status. "32

Same as the first respondent, the prior wife also promised the same dowry, then divorced at six month later. In an interview moment, the former of respondent's husband justify his former of wife that he reject to repay the dowry. In a separate interview, the husband of the respondent confirmed that he indeed refused to pay the dowry which was still owed to his two divorced wives on the grounds that his two ex-wives were not religious or 'salihah' women.

"I was indeed promising hajj tickets for dowry, but that is only true if my wives are sholihah. In fact, what do they do? They defended their sons than her husband, his son with their ex-husbands brought here, how can I see that? So what is wrong if I divorce? I do not want to pay the dowry; I prepare many lawyers so they cannot take what I have from this house. "33

The above statement of male respondents in terms of both state law and Islamic law has no justification. However, the reality shows that the two wives are powerless to fight for their rights and are forced to give up their rights.

\section{c. Does Not Get the Share of Matrimonial Property}

Two female respondents were forced to accept divorce by their husbands, but their right to community property was released. The compulsion of the first respondent to give up the right to matrimonial property was caused by his defeat against the dominance of his husband's extended family who intervened in his household by suppressing her husband to divorce and take the possession of his property. At the time of divorce, the respondent and her husband are in the stage of preparation to build a house, among others, make their own bricks as many as 8000 pieces, have bought stones, cement and iron for the foundation. For three years of marriage, they both worked hard to earn the money. Her husband went to Malaysia for two years, while she planted seaweed and opened a grocery store in her village

\footnotetext{
32 Interview with Yulinah as the respondent on September, 302016
}

33 Interview with Fadli as the respondent on October, 262016 
market. ${ }^{34}$ She mentioned that the urban village head was actually trying to mediate her case, but in mediation her mother-in-law dominated the forum and said that the respondent had brought her husband's money that he earned by working in Malaysia. According to her, the money she spent for building materials to make a house, but her parents-in-law insisted that she had spent it. In the forum, she did not get a chance to prove that the money to buy the building materials she had collected was her husband's money, while for everyday life she used her own money from trading and growing seaweed. In addition to failing to get her right to the community property, she was also helpless to collect in-law loan of gold necklace weighing of 3.5 grams. ${ }^{35}$

"I have made 8000 bricks, have bought a lot of building materials, yet I never took them with me, they are all taken by in-laws. All I got are trade gifts, plates, glasses, from blue wings, it is really unfair. I cannot take a new two-month slenso machine either. I got nothing. My family had helped demanding to kadus' house, my uncle, my brother, my sisters went to the kadus' house, but the result was nothing. "36

The narrative of the defeat of negotiation which led to the releasing of matrimonial property rights was also experienced by a female respondent from the Racing village. He said, "I had to give up because I want him to divorce me rather than watching him marrying someone else while being my husband". ${ }^{37}$ The respondents said that she had married for 22 years, she has collected some property, including rice fields, land and houses, two motorcycles. According to her, she wanted to be divorced but the desire came after she had to face difficult situation caused by the husband. Her husband said that he would marry another woman. She spontaneously expressed disagreement because in her opinion they did not have any issue in their marriage. She felt that she had been a faithful and understanding wife, she was still able to carry out all the obligations as a wife. She was unable to accept his husband's request. However, her husband desire to marry another woman cannot be stopped. Based on the story

${ }^{34}$ Interview with Rohawi as respondent on January 25, 2015

35Interview with Rohawi as respondent on January, 252015

36 Interview with Rohawi as respondent on January, 252015

37Interview with Samah as respondent on July 10, 2015 
mentioned above, the respondent finally made a decision and ask for divorce even though she still loves her husband. When the husband was agree to divorce her, she asked for the property they have collected together during the marriage to be divided into two. Her husband rejected the request on the grounds that it was her who wanted the divorce and not the husband. Due to unsuccessful negotiation she finally gave up and went home with no valuable possession. She only brought her clothes and glassware. ${ }^{38}$

"I'm hurt, and I am still not okay, especially when I see the house. We build the house together, but it goes to him after divorce, occupied with his wife. I built the house, I helped carrying water, which is not near, I also helped carry the bricks, sand. The house was the fruit of our sweats. We also have two motorcycles, after divorce, one motorcycle went to him, one for the child, but since the child went with him then the motor is in the house. I hate him"39

In the above case it appears that the husband make use of the psychological urges of wives who refuse to be polygamous relationship by taking advantage of the possession of all of their possessions, especially those built from the work after marriage. This husband's act is a violation of the wife's rights, because under the Marital Law Article 36 the property acquired after marriage takes place is included in the category of matrimonial property. The arrangement of the matrimonial property is subsequently found in Article 36 stating that the matrimonial property of a spouse may act upon mutual consent. According to Judiasih, this provision reflects an equal standing over the power of matrimonial property in marriage. ${ }^{40}$ This equality is further stated in Article $97 \mathrm{KHI}$ stating that the divorced widow or widower shall each be entitled to one half of the matrimonial property as long as it is not specified otherwise in the marriage agreement.

\section{d. Does Not Receive Legal Certainty about Her Status As a Widow} Juridically, unilateral divorce cannot decide the marriage registered by state law. However, the customs and religions of

\footnotetext{
38Interview with Samah as respondent on July 10, 2015

${ }^{39}$ Interview with Samah as respondent on July 10, 2015

40 Sony Dewi Judiasih, Harta Benda Perkawinan, (Bandung: Refika Aditama, 2015), 25
} 
unmarried women believe that they have become widow after her husband's divorce statements. On one hand, this belief makes them give up the rights as a wife that has not been fulfilled by her exhusband, but on the other hand the women has some obstacles to perform legal acts relating to her status.

The uncertainty of their marital status can, for example, be seen from the experience of a respondent from Kelor village and a respondent from the Balap village. The respondents from the Kelor village reported that she had been married three times. Her first marriage to a civil servant was registered in KUA and ended with the death of her husband. After her iddah period was over, she remarried a businessman formally in KUA. This second marriage ended in a unilateral divorce, and her third marriage to a merchant was privately arranged and ended in divorce at her request and her husband's consent. ${ }^{41}$

Normatively, based on Article 28 of Law Number 11 of 1969 concerning Employee Retirement and Widow/Widower Employee, Law Number 5 of 2014 on State Civil Apparatus, Government Regulation Number 37 Year 2017 concerning Stipulation of Retirement of Retired Civil Servant and Widow/Widower, because no longer bound in marriage with each other, the respondent is entitled to get her first husband's pension fund. ${ }^{42}$ However, because

41Interview with Mega as respondent on January 27, 2015

42Article 28 of Law Number 11 Year 1969 concerning Employee Retirement and Widow/Widowage Employee Retirement: (1) Pensions of widow/widower or part of penions of widow/widower are granted to the widow/widower who have no children, are aborted if the widow/widower marry again, calculated from the next month of the marriage. (2) If it is then specified in the case of the widow (widows) of the marriage referred to in paragraph (1) of this article is disconnected, then from the following month the widow shall be given another widow-pension or the part of the retired-widow which has been canceled, or if more profitable, to him was given a widow-pension which according to this Law can be obtained because of the last marriage.

Article 130 of Law No. 5 of 2014 on the State Civil Apparatus: At the time of its coming into force, Law Number 11 Year 1969 concerning Employee Retirement and Pension of Widow/Widower Employee (State Gazette of the Republic of Indonesia Year 1969 Number 42, Supplement State Gazette of the Republic of Indonesia Number 2906) and its implementing regulations shall remain in force until the enactment of the implementing regulations of this Law regulating the civil servant pension program Article 2 letter c PP Number 37 of 2014 on Stipulation of Retirement 
divorce with her second husband is unilaterally and cannot be proven by the divorce certificate, the status of the respondent before the law is the widow of civil servant who has remarried another person. This status causes his rights to the pension funds cannot be received. This indicates that unilateral divorce is to weaken women's participation in fulfillment of their right, especially widow of civil servant in receiving their economic rights.

The second respondent, recounted that she was unilaterally divorced by her husband. As is usually the case of unilateral divorce, she has a divorce certificate made with the help of urban village head. Six months later, she intended to remarry another man from Sumbawa. Unlike a new marriage with a fellow Lombok, her divorce statement cannot be used for the requirement of remarriage with the Sumbawa citizen. ${ }^{43} \mathrm{Her}$ new marriage registration will be accepted if she attach the divorce certificate from the religious court as determined by the provisions of the legislation. The above respondents' experience shows the disadvantage of women's participation in the fulfillment of the rights of widows, namely the right to remarry someone else to be recorded. A letter of divorce that local people believe to be an official letter because it is issued and confirmed by the government officials cannot be used as a proof of the divorce when it will be used in other area. The unilateral divorce validity standard applicable in Lombok cannot be recognized nationally because it is not in accordance with national legislation.

Another respondent who had the same problem recounted that her husband had verbally divorce her in front of his extended family, but until a year later he was unwilling to sign a divorce certificate. However, her former husband was able to marry another woman. This makes the respondents feel very disturbed because there is a feeling as if she was in a polygamous marriage, when in fact they have ended the marriage a year ago.44 Another experience of a

of Retired Civil Servant and Widow/Widower: a retired widow/widower of a Civil Servant who have retired on January 1, 2014 and prior to January 1, 2014, his pension is adjusted to be as listed in line 3 in line with the old basic pension as contained in column 2 of List VII-A up to List VII -Q Appendix VII which is an integral part of this Government Regulation.

43Interview with Samah as respondent on July 10, 2015

44Interview with Adila as the respondent on September 30, 2016 
respondent who was divorced over the telephone when she was in Saudi Arabia. Because the unilateral divorce was only done by phone, many people still think she is still the wife of her ex-husband. She then became the target of debt collector on behalf of her former husband who at that time has remarried. 45

The experience shows that even if the wife has been divorced, the respondent cannot enjoy her rights as a person who is no longer tied to her ex-husband. She still has to pay her husband's debt because someone else is considered to be the wife of her ex-husband and is therefore obliged to bear the debt. This situation can be avoided if the respondent has a divorce certificate issued by the religious court because the divorce certificate has the perfect legal power to prove the ending of the marriage which means breaking all of the consequences of marriage law.

In perspective theory of feminist law, studying practice in the community considered important than just reading the regulations law. It ensures if the intended rules for protecting women truly work effectively so women feel justice, or only give guarantee justice of the legal provisions. Related to this, feminist distinguish two type justice, namely substantive justice for the type of justice that really could be felt, and formal justice for the type of justice that just limited to legal provisions. ${ }^{46}$

Reviewed from gender perspective, rights violation of the Sasak women could be categorized as as marginalization, namely a process of marginalization to women who cause loss chance for get access of equal rights with man. It is said marginalization because the violation happen systematicly through support of social values and interpretation of religious law that is not fair. Referring on Quraishi, from its source aspect, marginalization to women could be sourced from government policy, beliefs, religious interpretations, traditions or habits, even science knowledge assumption..$^{47}$ In this, interpretation

\footnotetext{
45Interview with Murni as respondent on September 30, 2016

46 I Nengah Ardika, "Pemberian Hak Waris bagi Anak Perempuan di Bali dalam Perspektif Keadilan", Jurnal Magister Hukum Udayana, Vol 5 Nomor 4 ( August, 2016) https://ojs.unud.ac.id/index.php/jmhu/article/view/21741, accessed on Februari 282018.

47Hidayah Quraisy, "Kesetaraan Gender Pegawai Dinas Pertanian”, Jurnal Equilibrium Pendidikan Sosiologi, Volume III No. 1 (May, 2015), 
on religious law that is not fair could be found from meaning of divorce that is emphasized on aspect power of the husband, without equipped with aspect responsibility of the divorce use and obligations effect the actual divorce arranged with complete in Islamic law sources. As for law materials that empowers women no known by community because no socialized as it is material law that perpetuates power.

According to Widodo, as quoted by Mustika, marginalization to women could happen in economic field, social, cultural, political as well law. ${ }^{48}$ in this research, the ongoing marginalization could be categorized in three fields, namely law, economics and social field. In law field, it can seen that unilateral divorce practice cause women lost equal rights with man for being the subject of divorce law, and shifted to be objects that at any time could divorced by her husband. When her husband stated divorced, there is no institutions that can give law protection optimally for women to state her attitude on law, both the approval or rejection along with her law argument. Normatively, stated attitude law on desire divorced who originated from husband, is women right which are guaranteed by Marriage Constitution, however this right is lost by unilateral divorce practice that are socially recognized and justified by the community. There is troubling social values for women to seek the right fulfillment, among other things, values that emphasize that women receive her husband's decision without need to sued, and values that emphasize women should feel shame for asking something from the former husband.

Shifting position from subject law to object law, further will cause the emersion other impacts which is economy, that is loss chance for getting mut'ah right, livelihood of iddah, repayment dowry, and fulfillment right on the property. These fourth right represents women right for have property and enjoy welfare, because of that the violation to these fourth right logically gives impact on losing chance

https://media.neliti.com/media/publications/60772-ID-kesetaraan-gender-pegawaidinas-pertania.pdf, accessed on Februari 272018

48 Mustika, "Diskriminasi terhadap Beberapa Perempuan dalam Perspektif Feminisme Multikultural: Kajian terhadap Novel Scappa Per Amore Karya Dini Fitria", Jurnal Poetika, Vol. IV No. 1, (July, 2016), https://jurnal.ugm.ac.id/poetika/article/download/13313/9530, accessed on Februari, 262018 
for enjoying prosperity. Related with this, statement by Edriana Nurdin is not excessive that divorce on community Sasak is a process of impoverishment to women. ${ }^{49}$ Impoverishment to women who are legitimized through social values is one form process that by Naila Kabeer is called feminization poverty. .50

Relate with this impoverishment, a very reasoned opinion expressed Mansour Fakih, that marginalization is one of the five indicators of gender inequality, in addition indicators of stereotypes, subordination, violence and double load.51 Women who experience marginalization will be more difficult in reaching welfare because chance for being prosperous are intentionally reduced. ${ }^{52}$ Abandonment against the process of marginalization in long period could cause the marginalized person experiencing dehumanization process, which is lossing his humanity dignity. ${ }^{53}$ However, in broad perspective, women and man indeed become victims and experience dehumanization, where women experience injustice, while man considered to do oppression. ${ }^{54}$ By general it could be said that law settings about women rights effect divorce not yet could realize substantive justice for women on Sasak community, but rather just a

49 Edriana Noerdin, “Organisasi Perempuan di Tengah Keterbukaan Politik”, Jurnal Afirmasi, Vol. 02, (January, 2013), 22.

50 Naila Kabeer, "Gender, Poverty, and Inequality: A Brief History of Feminist Contributions in the Field of International", Gender and Development Journal, Vol. 23, No. 2, (July," 2015), 189-205, https://www.tandfonline.com/doi/pdf/10.1080/13552074.2015.1062300?needAccess =trueDevelopment, accessed on Februari, 272018

51 Mansour Fakih, Analisis Gender dan Transformasi Sosial, (Yogyakarta: Insist Press, 1996), 73

52 Nancy Janovicek, "Women, Social Policy and Poverty", Journal of The History of The Atlanthic Region, Vol. XXXVI, No. 1 (Autumn, 2006), 1. https://journals.lib.unb.ca/index.php/acadiensis/article/view/5728/11199, accessed on February 28, 2018.

53 Nick Haslam, "Dehumanization, An Integrative Review", Jurnal Personality and Personal Psychology Review, Vol. 10 No 3, (2006), 252-264, http://journals.sagepub.com/doi/pdf/10.1207/s15327957pspr1003_4, accessed on 27 Februari 2018.

54 Palung Anggi Yuwono dan Nuraini W Prasodjo, “Analisis Gender pada Program Pengembangan Usaha Agribisnis Pedesaan (PUAP), Jurnal Sodality, Vol. 2 No. 1, (August, 2013) 131-151. http://journal.ipb.ac.id/index.php/sodality/article/view/9399/7364, accessed on tanggal 27 Februari 2018. 
limited legal provisions of formal justice. It is not yet in line with ambition justice that is aspired by Convention Deletion All Form of Discrimination to Women who agreed by women messenger all over the world on 1979 and has been ratified by Government Republic Indonesia through Constitution Number 7 Year 1984 about Endorsement Convention Deletion All Form Discrimination to Women. 55

\section{Conclusion}

Based on exposure above, it can concluded that conjecture of the existence violation of the women rights in practice of unilateral divorce on Sasak community proven to be correctly exist. With thus, the findings of this research strengthenthe feminist law theory, that realisticly the living law in the community tend to perpetuate man's power. In this context, the power that is perpetuated is power for divorce and dominate any number real property that actually is women's right. Sociologically, it is important to making a legal literacy program for Sasak community as reference to change their law behavior in the divorce in order to not divorce unilaterally anymore.

\section{Bibliography}

Anshary MK., Hukum Perkawinan di Indonesia, Masalah-masalah Krusial, Yogyakarta: Pustaka Pelajar, 2010.

Arto, Mukti. Mencari Keadilan, Kritik dan Solusi terhadap Praktik Peradilan Perdata di Indonesia, Yogyakarta: Pustaka Pelajar, 2001.

Blackburn, Susan. Kongres Perempuan Pertama, Tinjauan Ulang, Jakarta, Yayasan Obor Indonesia dan KITLV Belanda, 2007.

55 Anu Saksena, CEDAW: "Mandate for Substantive Equality", Indian Journal of Gender Studies , 14:3 (2007): 481-498 SAGE Publications Los ngeles/London/New Delhi/Singapore DOI: 10.1177/097152150701400306, http://journals.sagepub.com/doi/pdf/10.1177/097152150701400306, accessed on 28 Februari 2018. 
Bungin, Burhan. (Ed), Metodologi Penelitian Kualitatif, Aktualisasi Metodologis ke Arah Ragam Varian Kontemporer, Jakarta, Rajawali Pers, 2011.

Fanani, Zainuddin bin Abdul Azizi Al Malibari Al, Fath al-Mu'in, Translated by: Moc. Anwar, Bandung: Sinar Baru Algesindo, 2014.

Fakih, Mansour. Analisis Gender dan Transformasi Sosial, Yogyakarta, Insist Press, 1996.

Harahap, Yahya. Kedudukan, Kewenangan dan Acara Peradilan Agama, Jakarta: Garuda, Metropolitan Press, 1993.

Herdiansyah, Haris, Wawancara, Observasi dan Focus Group sebagai Instrumen Penggalian Data Kualitatif, Rajawali Pers, Jakarta, 2013.

Intruksi Presiden Nomor 1 Tahun 1991 tentang Penyebarluasan Kompilasi Hukum Islam, Departemem Agama Republik Indonesia.

Judiasih, Sony Dewi. Harta Benda Perkawinan, Bandung, Refika Aditama, 2015.

Miles, Mathew dan Michael Huberman, Analisis Data Kualitatif, Jakarta, UI Press, 1992.

Nuruddin, Amiur dan Azhari Akmal Tarigan, Hukum Perdata Islam di Indonesia: Studi Kritis Perkembangan Hukum Islam dari Fikih, UU No. 1/1974, sampai KHI, Jakarta, Kencana, 2004.

Peraturan Pemerintah Nomor 9 Tahun 1975 tentang Pelaksanaan UndangUndang Nomor 1 Tahun 1974 tentang Perkawinan.

Syawkani al-, Nail al Author, Jilid 6, Beirut: Dar al Fikr.

Syaifuddin, Muhammad. Sri Turatmiyah. Annalisa Yahanan, Hukum Perceraian, Jakarta, Sinar Grafika, 2013.

Tamtiari, Wini. Awig-awig Melindungi Perempuan dari Kekerasan?, Yogyakarta: PSKK, UGM dan Ford Foundation, 2005.

Undang-Undang Nomor 1 Tahun 1974 tentang Perkawinan, (Lembaran Negara Republik Indonesia tahun 1975 No. 12; tambahan lembaran negara RI tahun 1975 No. 3050)

Undang-Undang Nomor 11 Tahun 1969 tentang Pensiun Pegawai dan Pensiun Janda/Duda Pegawai, (Lembaran Negara Tahun 1969 Nomor 42, Tambahan Lembaran Negara Nomor 2906)

Wahyudi, Hamzan. "Tradisi Kawin Cerai Masyarakat Adat Suku Sasak serta Akibat Hukum yang Ditimbulkan", Tesis, 
Program Pascasarjana Universitas Diponegoro Semarang, 2004.

Widanti, Agnes. Hukum Berkeadilan Jender, Aksi Interaksi Kelompok Buruh Perempuan dalam Perubahan Sosial, Jakarta: Kompas, 2005.

Yasin, Nur. Praktik Kawin Cerai Bawah Tangan di Kalangan Masyarakat Muslim Sasak di Kota Mataram, Malang: UIN Maliki Press, 2008.

Zulfatun Ni'mah dan Nur Fadhilah, "Pluralisme Hukum Perceraian pada Masyarakat Sasak di Pulau Lombok dan Implikasinya terhadap Pelaksanaan Hak-hak Perempuan Pascaperceraian", Repport of Research, Not published, 2016.

\section{Journals}

Ardika, I Nengah. "Pemberian Hak Waris bagi Anak Perempuan di Bali dalam Perspektif Keadilan", Jurnal Magister Hukum Udayana, Vol 5 Nomor 4 ( August, 2016) https://ojs.unud.ac.id/index.php/jmhu/article/view/21741 , (accessed on Februari 28 2018).

Haslam, Nick. "Dehumanization, An Integrative Review", Jurnal Personality and Personal Psychology Review, Vol. 10 No 3, (2006), http://journals.sagepub.com/doi/pdf/10.1207/s15327957ps pr1003_4 (accessed on 27 Februari 2018).

Janovicek, Nancy. "Women, Social Policy and Poverty", Journal of The History of The Atlanthic Region, Vol. XXXVI, No. 1 (Autumn, 2006),

https://journals.lib.unb.ca/index.php/acadiensis/article/vi ew/5728/11199, (accessed on February 28, 2018).

Kabeer, Naila. "Gender, Poverty, and Inequality: A Brief History of Feminist Contributions in the Field of International", Gender and Development Journal, Vol. 23, No. 2, (July,, 2015).

https://www.tandfonline.com/doi/pdf/10.1080/13552074.2015.1062 300?needAccess=trueDevelopment, (accessed on Februari, 27 2018)

Mustika, “Diskriminasi terhadap Beberapa Perempuan dalam Perspektif Feminisme Multikultural: Kajian terhadap Novel Scappa Per Amore Karya Dini Fitria", Jurnal Poetika, Vol. IV 
No. 1, (July, 2016), https://jurnal.ugm.ac.id/poetika/article/download/13313/ 9530, (accessed on Februari, 26 2018).

Noerdin, Edriana. “Organisasi Perempuan di Tengah Keterbukaan Politik", Jurnal Afirmasi, Vol. 02, (January, 2013).

Quraisy, Hidayah. "Kesetaraan Gender Pegawai Dinas Pertanian", Jurnal Equilibrium Pendidikan Sosiologi, Volume III No. 1 (May, 2015), https://media.neliti.com/media/publications/60772ID-kesetaraan-gender-pegawai-dinas-pertania.pdf, (accessed on Februari 27 2018)

Saksena, Anu. "CEDAW: "Mandate for Substantive Equality", Indian Journal of Gender Studies (2007) SAGE Publications Los Angeles/London/New Delhi/Singapore DOI: 10.1177/097152150701400306, http://journals.sagepub.com/doi/pdf/10.1177/09715215070 1400306, (accessed on 28 Februari 2018).

Snider, Emily. "Indigenous Feminist Legal Theory", https://www.utpjournals.press/doi/full/10.3138/cjwl.26.2. 07, (diakses tanggal 27 Februari 2018).

Susylawati, Eka. Moh. Masyhur Abadi, H. M. Latief Mahmud, "Pelaksanaan Putusan Nafkah Istri Pasca Cerai Talak di Pengadilan agama Pamekasan, Jurnal Al Ihkam, STAI Pamekasan, Vol. 8. No. 2 Tahun 2013, http://ejournal.stainpamekasan.ac.id/index.php/alihkam/article /view/354/345, diakses tanggal 1 Mei 2018.

Yuwono, Palung Anggi and Nuraini W Prasodjo, “Analisis Gender pada Program Pengembangan Usaha Agribisnis Pedesaan (PUAP), Jurnal Sodality, Vol. 2 No. 1, (August, 2013). http://journal.ipb.ac.id/index.php/sodality/article/view/9 399/7364, (accessed on tanggal 27 Februari 2018). 